\title{
Inspiration and Evaluation of Paintings of Cezanne
}

\author{
Mani Nandini Sharma \& Ila Gupta \\ Department of Humanities and Social Sciences, Indian Institute of Technology, Roorkee, \\ Uttarakhand.India.Email: manisharma2075@gmail.com.
}

Received December 02, 2016; Accepted December 25, 2016; Published January 26, 2017

\begin{abstract}
Cezanne is a painter who existed in the era of discoveries, there was law of relativity as well as discontinuous travel of light. Despite all the scientificised discoveries and inventions, Cezanne was seeking inspiration from nature. Nature was the sole inspirer of him. Nature, he wanted to tap, the structure of, underneath in his paintings. During the times earlier to mid nineteenth century, symmetry was essential aspect of art as understructure, as in Piero della Francesca's artworks. During mid nineteenth century art was paving way to new paradigms. Painters display emotion, sentiment, capturing of form, structure, composition with line, color or form to fathom their artistic instincts. Here in this paper I display the luminous use of color by Cezanne and use of hidden geometry in the painting of Mont Sainte Victoire to elucidate his traits to capture nature to its truest form, asymmetry. In understructure also, this asymmetry is vocal in the pentagon formed at the focal point of painting. Our earth is the worthy example of asymmetry. As nature (earth) is asymmetrical so we find traits of asymmetry in Cezanne's understructure of painting. The inspiration of the artist lay in nature, so was his treatment of painting.
\end{abstract}

Keywords: Font Geometry, Symmetry, Asymmetry, Pentagon, Nature

\section{Introduction}

'If nature were all lawful then every phenomenon would share the full symmetry...' (Weyl, 1952, 26)

Ian Stewart says that though earth is considered an elliptical sphere but an irregular volume with little more attention on it. Other than this the earth has mountains, trees, plains, buildings, cityscapes, trees, plants. plants have leaves and flowers on its branches- irregular surface with lot of variations on the surface. Otherwise also Earth is not a smooth surfaced elliptical object when seen in context of an individual planet, Earth has no smooth surface. If symmetry does not exist in nature, even then artists and historians have geometricized and provided symmetry as an understructure to paintings. It must have been to bring one's identity to the existence and recommending worth to their own creation. Cezanne was born in France in the era of steam. Steam engine in trains with the first locomotive "Northumbrian", new discoveries were emerging, division of body and soul, human thinking leading to the forefront human consciousness and the concepts of motion and processes. Marx Darwin's principle of interchangeability of different forms of energy with the dwelling into the relationship of one event leading to another was

(c) AesthetixMS 2016. This Open Access article is published under a Creative Commons Attribution Non-Commercial 4.0 International License (http://creativecommons.org/licenses/by-nc/4.o/), which permits non-commercial re-use, distribution, and reproduction in any medium, provided the original work is properly cited. For citation use the DOI. For commercial re-use, please contact editor@chitrolekha.com 
evolving. The same relationship between nature and society was shared in concept of space. The understanding and explanations of things was understood as the minute particles surrounding things; i.e. the space lying between the things but not the things in itself, the essence of the thing was understood as the minuscule particles encircling [the things], then, not in the thing itself. The dialectical nature of materialism was formulating in the field of science and human research. In the electricity the concept of the field of electromagnetism was evaluated so was in 1870 the electromagnetic theory of light was formulated, in 1901, five years before the death of Cezanne, Max Planck published quantum theory, in 1905 Einstein came with revolutionary theory of Relativity. Einstein suggested that light travel through space in discontinuous quanta, one constant was speed of light and other measurements were to the position and motion of the observer. This concept of space and time were also the constituents of formulation of art analysis by art historians and art critics. With Cezanne it was nature as the sole inspiration for creating works of art. Nature which exists of earth, and if, earth in itself is a non symmetrical sphere, then how Cezanne could break the omnipresent law of asymmetry.

Cezanne was born in a banker's family at Aix-en-Provence in France on the 19th day of January, 1839. He pursued law according to the wish of his father. He, side by side, carried further his passion of learning painting at Academie Suisse at Aix. From 1862 till 1877, he kept working at Paris, Auvers, Pontoise and more frequently at Aix. Writer Emile Zola, one of his closest friends from Provence, was in Paris with whom Cezanne interacted and worked in close integration. Finally, in 1878, he retreated to his native place Aix to work in communion with nature. Earlier to mid 7o's Cezanne was all engrossed in high romantic subjects with dark fantasies and impasto brushwork. The imaginative art works were impasto with dark colors. Cezanne gave much credit to Camille Pissarro, the earnest impressionist observer of nature, who took him for series of walks and tours through the landscape of Auvers and Pontoise and brought Cézanne out of the dark murk of the religious and mythological paintings. Pissarro's art, at this point of time, took Cezanne beyond his temptations, eroticism and dark phase of his artistic career. Their friendship had a lasting impact on Cezanne and his expression in painting. The sculpting of Cezanne's colors dipped in the sausages and garnishing of the earlier masters, took a leap with the understanding of impressionist colors and practice as articulated by Pissarro. To Cezanne mere recording and painting of light sensations did not give any satisfaction. He wanted more than this, something that could satisfy his underlying urge of expression. The brush work was rarely to catch only the texture or surface of the object. His interest was to express his vision of penetration of the object to the structural component. The sensations of nature, his desire to capture, with its underlying structure, the sensations captured collectively in volume with brushstrokes that were constructive with the modulation of color. The recognition of his desire, laid in the whole of the composition, does not extend farther than the two dimensions of picture plane. As Loran quotes '... the picture, regardless if the exigencies of the subject represented, must remain faithful to its own structure, to its fundamental two dimensions.' (Loran, 1950) From now onwards, Cezanne's paintings were a record of not visual perceptions. He painted on canvas with multiple viewpoints of different locations and stand points. Cezanne fathomed no single view point could do justice to the nature. His era of discoveries and inventions had impacted his art in quest for the search of underlying truth beneath the appearances of the nature and was fundamental to his search for formula. The aim of this paper is to portray the influences on Cezanne, and the way Piero della Francesca had impacted him. The study also incorporates the hidden geometry in paintings of both the artist. The geometrical figure is pentagon, which is brought apparent in the artworks. As Roger Fry says, underneath geometry of Cezanne, laid a central triangle, flanked by two triangles, one on either side. (Fry, 85) The scientific perspective of Piero della Francesca is a direct influence 
on Cezanne. Cezanne comes amongst the foremost one, other than Delacroix and Rubens and Veronese. Scientific perspective of Francesca is totally amended, as Cezanne overcame it and put the sacred symbol in his own terms. Cezanne's use of Pentagon, as is apparent in Francesca, to elate the focal point leads to a new vocabulary of underlying geometry. The concern of the paper is a sacred geometrical figure in the artworks of Cezanne. He put understructure geometry in his own terms. '...art is like logic, the history of which is to be sought in what men have done and not in the books they have written on logic.' (Ivins jr, 1946, 11) Fundamental to his quest of nature other than triangles was pentagon articulated on two dimensions of canvas. The pentagon he distorted, as he did the objects, to achieve the desired effect of objects belonging to the spectator, though they belong to two dimensions of the picture plane. Despite it, temptation to grab the objects, they are at the same time engrossed in their own world of the canvas dimensions. Cezanne had the similar traits in his lifestyle also. At one place he was making an art which was to turn the way of art scenario totally, and, on the other he was the solitary artist, reclusive to his native place, Aix-en-Provence. In his life style, regular walks to his motifs and listening to the melodious chorus sung in the church were a part and parcel.

\section{Inspirations of Cezanne}

It was only in 1910, that the then art critic, Roger Fry, coined the term, post-impressionism, in London for an exhibition 'Manet and the Impressionists'. Despite of adverse criticism Roger Fry adhered to the notion that these artists followed on the tradition of the old masters. Artists Seurat, Van Gogh, Gauguin and Cezanne were the leading artists of the movement. Composition supremacy, enhanced color, novelty in technique, spiritual intent, sentiments and nature were prime concern. Post-impressionism, was the reaction against impressionism of 1870's and 1880's. The last quarter of nineteenth century was the era of impressionism. The consistent artists were a year or two younger or older to one or another. Cezanne was a year older to Monet or same age as Sisley, admirer of Monet and follower of Pissarro, retained with Renoir and Monet, Pissarro proved to be Cezanne's mentor. To bring about the color understanding of Cezanne, certain influential amendments were brought about the color and understanding of nature and art.

Pissarro's art at this point of time took Cezanne beyond his temptations, eroticism and dark phase of his artistic career. Their friendship had a lasting impact on Cezanne and his expression in painting. Earlier to mid 70's Cezanne was all engrossed in high romantic subjects with dark fantasies and impasto brisk brush work. Prominent influences on impressionists and Cezanne were of Delacroix, Daumier and Courbet. The sculpting of Cezanne's colors dipped in the sausages and garnishing of the earlier Masters, took a leap with the theoretical understanding of impressionist colors and practice as articulated by Pissarro. 'The art of painting, said in Book II of De pictura, comprehends three parts: circumscription, composition and distribution of light. For these words Piero della Francesca substitutes design, measures and color. The nuance is interesting: Piero is thinking as a painter, he uses the more precise word design, and reflect with penetration upon the text of his source, discovered something that the modern painters did not understand until Cezanne- that the distribution of light is a problem of color.' (Bouleau, p. 92) It was clear to Cezanne that mere recording and painting of light sensations would not satisfy him. He wanted more that could satisfy his underlying urge of expression. His desire to capture sensations of nature, with its underlying structure and objective of sensations captured collectively in modulation, with brushstrokes, that were constructive with color. The brush work was rarely only to catch the texture or surface of object. His sheer interest was to express his penetration of vision to the structural component of the object. The recognition of his desire laid 
in the whole of the composition does not extend farther than the two dimensions of the picture plane. The objects belonged to the group and the group had its own identity as every object had the legacy to enjoy.

Cezanne's utter desire was to tap the legacy to make a history and make art for museums, Cezanne wanted to be amongst the Masters and devise the underlying formula as they did in their art. This he derived while learning from the Masters at Louvre, in Paris. 'Still Life with Blue Pot' is very appropriate here to mention. Substantial volume is added to the objects for sustaining their presence on the canvas dimensions. Objects for the sake of the two dimensional surface, Cezanne made objects pertaining to the space of these dimensions. The meaning to outward world was fully compiled inside the composition only. Cezanne made objects for their own sake. A flake of white snow according to his meaning incorporated whole of the surroundings in itself. He would say if he had captured all of the blues and violets on a canvas. Pertaining portrait, he would have the model and her persona in the painting. He would let nothing escape or penetrate from his perception and sight, not even the odor. Once he said he could even see the odor. 'There is some plausibility... that Cezanne had a theory of vision... in which seeing does not reduce to an "objective" account of the "visible," since it also involves "blind" experiences of an "invisible" corresponding to the "palpation" of the objects with "the eye." (Smith, 102) In an instance with Madame Cezanne, on one of their journey, Cezanne halted to observe a motif. He would stand and perceive it for hours, from one place and then shifting to another place. First he would observe each and every angle possible. His observations tapped the sensations that the nature would identify itself in him, nature justified it and he would paint its sensations. It was his urge to do nature after Poussin. About his utter desire he used to converse with his young friend Emile Bernard: who spent time learning in Cezanne's studio and grasp his ideology. The young painter was a writer and critic too. His 'Letters of Cezanne' translated by Denchev (2013), incorporate many of his valuable interactions which motivated him to compact the ideology of otherwise not so social Cezanne. The prolific writing testifies Cezanne's ardent reading habits. He was a regular reader of Delacroix's treatise and Journals. His frequent letters to his son Paul, Bernard, Vollard, family friends and critics were a testimony to his writings, witty and cordial at the same time. Rewald narrates one such instance that a collector of Cezanne found him a very elegant and cultured man at meals she had ever met. In another instance that Cezanne admired Monet, and exclaimed that he has an eye but what an eye. His admiration was apparent when Monet extended his hand to Cezanne for a firm handshake, Cezanne denied out of courtesy saying that his hands were not clean enough to have a handshake with him.

\section{Geometry in Painting}

It is not only apples but also the underlying geometry that he made his own, as it was of the masters. From the ancient times, certain kind of geometry is incorporated to demonstrate space explicitly or implicitly in the art works. The division of art and architecture has been smaller than the human scale or is monumental. Either it is in form of hieratic scaling 'overlapping figures on the frontal plane (Kadar and Effken, 2008, 303) of Egyptians, or in the colossal expanding of scale in norms and art works of Romans. The ancients had it. Cezanne was most probably not interested in the horizontal eye level of the predecessors in this aspect as stated by Loran (1950). During middle age it seems apparent that the art had been a decline but with scrutinizing it speculatively, geometry becomes very ardent in proportions or scaling of human figure. In adverse conditions of dictatorship made Christ was made smaller in size, so were his subordinating elements. The early renaissance sees the underlying structure as linear space organization. Giotto, 
Masaccio, innovate the underlying structure as linear space organization which extended to scientific one in Renaissance period. Piero della Francesca extended the linear perspective to scientific perspective. He implemented theory of mathematics to architecture to calculate visual implications in painting and taking human as the measuring scale. Piero della Francesca's legacy of scientific explorations was brought to its zenith by Leonardo da Vinci. It saw its dawn with Giotto and sunshine in middle and High Renaissance. In his 'Last Supper' the symmetrical underlying geometry makes it a harmonious display of object and humans. The only asymmetry appears with the upward pointing finger of Judas with a raised hand. The source of light was from different angles, right, back or front from the windows and doors, unlike Francesca's whose light was falling from two different directions despite the source of light remaining one, the objects with minimal casted shadows and that too in same direction of light. For Piero it was the form, group, perspective and geometry now it came to the dynamism of line and color. Della's treatise was carried forward by Rubens and Delacroix. The writing of Delacroix in his journals emphasized on opposite colors, luminosity was achieved with the optical renaissance in color, achieved its zenith in Monet's 'Water Lilies' and 'Rouen Cathedral'. The scientificised optical mixing of contrasting colors is luminous, bright and well illuminated from light. The constitutions of light and color, till now, was the source of light falling from the rays of sun. A transformation was to come in the source of light, taking its legacy from the old master Piero della Francesca. In his painting 'Flagellation of Christ.' where more than one source of light is apparent also perspective is brought in existence with multiple vanishing points. This reached to its zenith in the multiple viewpoints of individual objects. In the painting by Francesca yellow and blue lines portray different perspective in the same painting and Turquoise blue marks the pentagon. This pentagon encapsulates the main subject matter- Christ flanked by figures on either side. These figures make possible the formation of pentagon. In the legend of true cross, Piero has demonstrated here his grasp of essentials by the balance created with broad contrast of planes. Each of the subsequent planes has its own marked rhythmic combat with the other, divides in two equal parts, by a clear, vertical, one square and one rectangle.

\section{Pentagon in painting}

Pentagon shares a divine place in art. In the ancient Greece the nomenclature of the present geometry is- "Geo" meaning "earth" and "metron" means "mesurment" and according to Merriam Webster dictionary, "geometry” means:

1. a: "a branch of mathematics that deals with the measurement, properties and relationships of point, angles, surfaces and solids: broadly the study of properties of given elements that remain invariant under specific transformations"

$$
\text { b: " a particular type of system of geometry" }
$$

2. a. "configuration"

b. "surface shape"

3. "An arrangement of objects or parts that suggest geometric figures"

When considering the definition 1. a., 'the outcome is the different angles, spheres, triangles, solids etc.' pentagon is one of the shapes which come under the heading of geometry. In greek, "pente" means five angles and "gonia" means angle"- a shape with five angles and every angle adjacent to that of central point measures 72 degree. Every angle adjacent to sides is 108 degrees. The pentagon has a perimeter, radius, 5 lines, height and bisecting lines. The pentagon 
can be made with a given circle or a side. Moreover pentagon is considered amongst sacred geometry as golden ratio comes in the making process. It is formed with the pentagram. Presence in the segments in the making of the pentagon and pentagram has certain proportions akin to the divine. During the Middle Ages pentagon had its essential place in making of paintings. During the medieval guilds construction of a pentagon was preferred with a circle instead of a side (with golden ratio). The most useful one, other than many ways pentagon can be constructed is with a circle- taking the example of Piero della Francesca's Flagellation of Christ, Figure1. b 'let there be a given circle keeping the heart of Christ as the center. Let the radius of this circle be the distance between the statue, adorning the pillar at the back of Christ, and the center of Christ's heart. Draw the diameters $\mathrm{AB}$ and $\mathrm{CD}$ perpendicular to one another. Let $\mathrm{A}$ be the point at the statue's head and $\mathrm{B}$ at the horizontal line, with black and white checkers, on the floor and make the tangents parallel to these DE and BE. Join EA. EA will intersect CD at F. Revolve FA upon C, giving point G: AG equals the side of the inscribed pentagon. Draw a line of length from $A$, intersecting the circle at $\mathrm{H}$. Draw similar lines $\mathrm{HJ}, \mathrm{JK}, \mathrm{KI}$ and IA. This establishes a pentagon. The golden section is produced by the intersection of any two diagonals of the pentagon, and also is the ratio of its side to its diagonal. This unique proportion, constantly recurring, enchanted the ancients and made them consider the pentagon as a perfect figure.' (Text amended according to the requirement of the paper) (Bouleau, 1975, p 64) Without going in too much of calculations and mathematical theorems and equations, the study incorporates the basic pattern of geometrypentagon which Cezanne used in his paintings akin to Francesca.

This conscious trait of his behavior was very apparent in his way of working. In his conversation with Bernard (Doran), when he said that he wanted to have a formula, as did the masters. 'Masters' had it from the golden section, musical connotations sacred geometry of pentagon, circle, hexagon, octagon and more. Piero della Francesca has the sacred pentagon in its due perimeters of sacred geometry. Pentagon so exactly around Christ as if especially made for his sacred space is in the left part of the division on canvas. This hidden geometry is not apparent in the geometrical line drawing on the surface of painting, but is hidden underneath as in 'Flagellation of Christ'. That gave an existence of a geometric pattern in form of perspective from two sides that he used as hidden geometry in his painting. In Cezanne's painting, his concise aim has been to establish his art on the two dimensions of the picture plane. The extension of the picture did not happen outside the canvas. It was more than this- the structure that incorporated both the glistening contrasting colors of objects and volume of the structure achieved with modulation. He said, 'There is no such thing as line or modelling,' he told Emile Bernard, 'there are only contrasts.' (Gowing, 1977) The contrast he achieved in apples, Cezanne would say that he would astonish Paris with an apple, which he extravagantly did during the later phase of his artistic career. Very mundane in his routine he would daily go to paint his motif, away from hustle-bustle and glamorous life of Paris, while his contemporaries were engrossed in the titillating life of Paris. In the making of the landscape of 'Mont Sainte Victoire Seen from Les Lauves' Figure: 4 . b, the painting is given a repeated pattern of triangle, one in the center and two on either side. In Francesca's, coming to the underlying geometry of it, the pentagon has the sacredness formed at, almost, the center of the picture. This is a regular pentagon formed with a circle. Though in case of Cezanne this in not the regular pentagon but monohedral pentagon. This type of pentagon is also used in tiling. Cezanne, as he distorted the perspective and objects, has also distorted the pentagon. This distortion can be further analyzed in the geometrical proving with theorems and equations. In the findings, it is found that his use of Pentagon emphasize the focal point with underlying geometry. The division of canvas on the basis of major proportions come almost to the half, more portion towards left. It is almost similar in both the 
paintings- Francesca's the Flagellation of Christ and Cezanne's Mont Sainte Victoire Seen from Les Lauves. The division is done on the basis of the pillar in the former one and formation of triangular foliages on left in the later. That there is more of movement on the left and lesser on left is apparent. When two people stand in front of each other, heart of one is opposite to the other. When one would stand in front of the painting, the movement, or the heart beat would be akin to the left of the other. Thus it is very apt that the artists have painted their sensations of heart in their paintings.

\section{Conclusion}

Cezanne is an artist of the repute that he changed the course of expression in art. Cezanne was a solitary artist of great discipline, determination and dedication. He proved his worth to the world with giving structure to the impressionist colors. Also, he carried forward the legacy to learn from the Masters and implementing it with his own language. Piero della Francesca was one such inspiration for Cezanne. Delacroix had the brilliancy of colors. Collectively he brought his own visual language, implementing it to nature in his artworks. The legacy from the masters was further forwarded by the revered artist. He distorted the objects. This aspect is also evident in the understructure surrounding the focal point in the paintings. In his quest of realizing nature he tapped the structure under the colors and light falling on the objects. In the underlying geometry, the evidence of a pentagon is apparent. It s a legacy taken from the Master Piero della Francesca. The triangles formation as said by Fry has two flanking asymmetrical triangles, one on either side. The findings show in the formation of the pentagon in both the Masters, though the literal evidences are not available from Cezanne's conversations and letters to his friends, critics, son, collectors and artists. The underlying geometry was the artist's own interpretation according to his understanding of nature. 


\section{List of Plates}
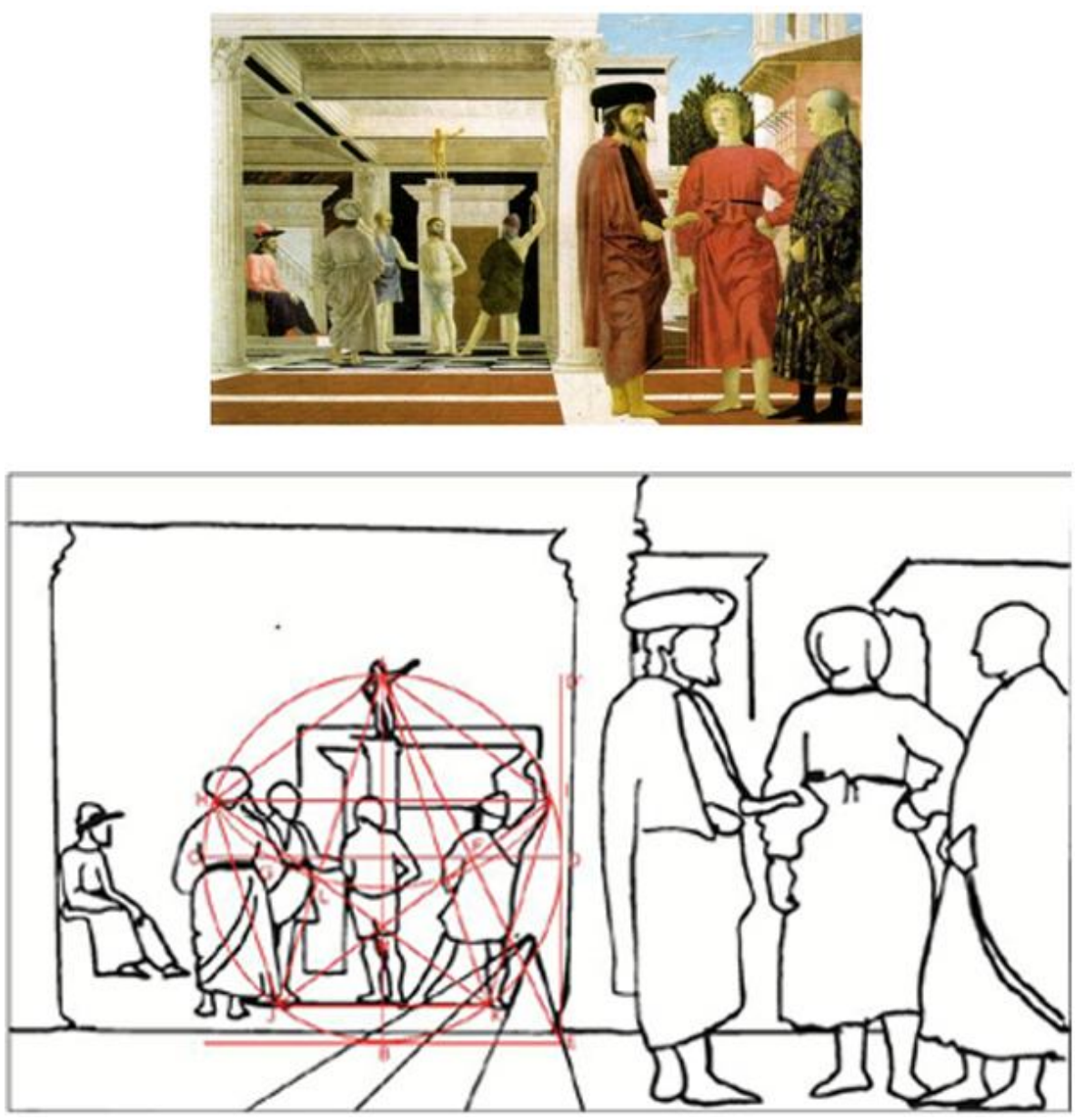

Figure: 1 a. Flagellation of Christ, Piero della Francesca, c. 1455-65, Oil and Tempera on wood, 58.4* 81.5 cm, Galleria Nzionale delle Marche, Urbino. Image Source:

https://en.wikipedia.org/wiki/Flagellation of Christ (Piero della Francesca)

Figure: 1 b. Line drawing of The Flagellation of Christ 


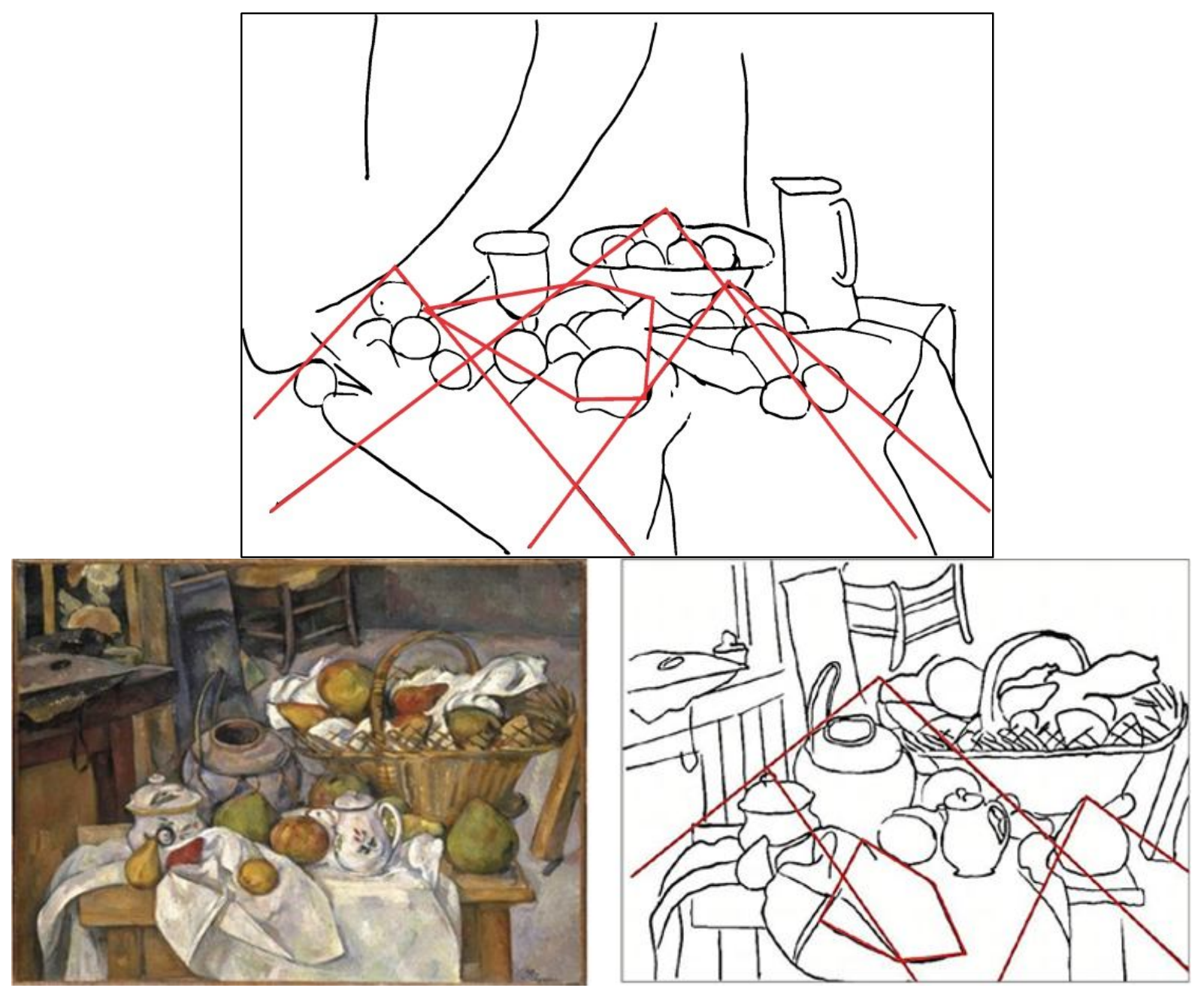

Figure: 2 . a. The Kitchen Table, $1888-90$, Oil on canvas, $25^{5 / 8} \times 31{ }^{1 / 2}$ in $(65 \times 80 \mathrm{~cm})$, Signed lower left in blue: P Cezanne, Musee d'Orsay, Paris. Image source: https://en.wikipedia.org/wiki/List of paintings by Paul C\%C3\%A9zanne

Figure: 2. b. Line drawing of The Kitchen table

Figure: 3. Line drawing of Still Life with Apples by Paul Cezanne, 1895-98, Oil on Canvas, 27 x $36^{1 / 2}$ in $(68.5$ x 92.7 cm) The Museum of Modern Art, New York (Little P. Bliss Collection)
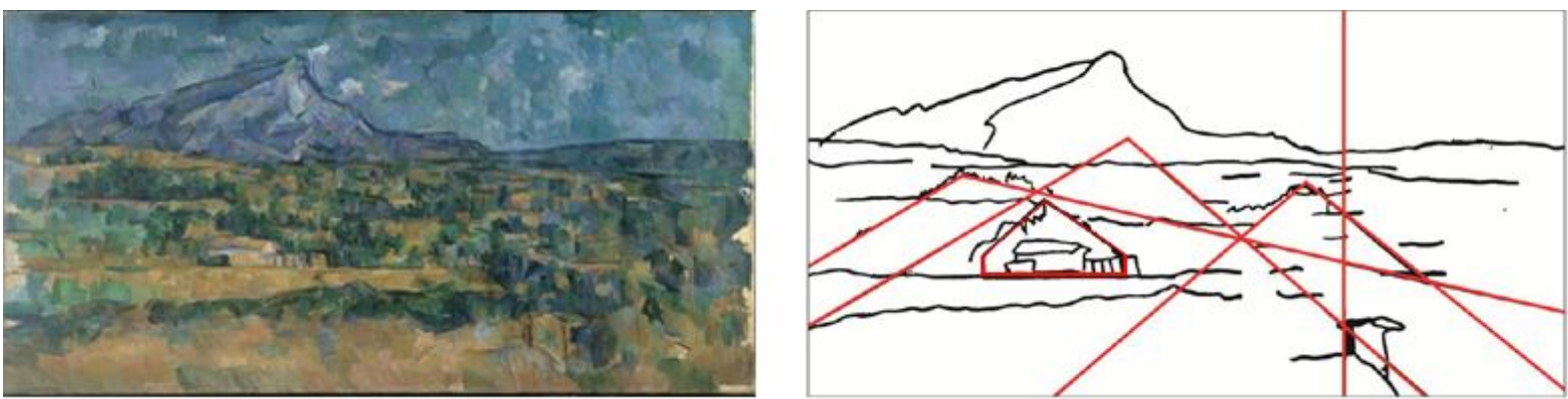

Figure: 4. a. Mont Sainte Victoire seen from Les Lauves, Artist : Paul Cezanne, ca. 1902-6, Oil on canvas, $22{ }^{1 / 2} \times 38^{1 / 4}$ in (57.2 x 97.2 cm), Paintings Credit Line : The Walter H. and Leonore Annenberg, Collection, Gift of Walter H. and Leonore Annenberg, 1994, Bequest of Walter H. Annenberg, 2002, Accession Number: 1994.420. Image Source: https://www.metmuseum.org/art/collection/search/435878

Figure: 4. b. Line drawing of Mont Sainte Victoire seen from Les Lauves 


\section{References}

Alsdorf, B. (2010). Interior Landscape: Metaphor and Meaning in Cezanne's Still-lifes. Word and Image: A Journal of Verbal/ Visual Enquiry, 26(4), 314-323. Retrieved 15 Dec. 2014, from http://dx.doi.org/10.1080/02666280903498201

Armstrong, C. (2004) Cezanne in Studio, Still Life in Water Colors Los Angeles: The Paul Getty Museum.

Bouleau, C. (1963). The Painter's Secret Geometry; a Study of Composition in Art. New York: Harcourt, Brace $\&$ World.

Danchev, A. (2013). The letters of Paul Cézanne. London: Thames and Hudson.

Cézanne, P., Reff, T., \& Rubin, W. (1977). Cézanne: The Late Work: Essays. New York: Museum of Modern Art. Fry, R. (1952). Cézanne: A Study of his Development (II ed.). London: Hogarth Press.

Fry, R. (nd). Cézanne: A Study of his Development (I ed.). New York: Noonday Press.

Gowing, L. (1977). Cézanne: The Late Work: Essays (W. Rubin, Ed.). New York: Museum of Modern Art. 5572

Grey, C. (1959). Cezanne's use of Perspective. College of Art Journal, 19(1), 54-64.

John Gilmour, C. (2000). Improvisations in Cezanne's Late Landscapes. The Journal of Aesthetics and the Arts, 52(2), 191-201. Retrieved 16 Nov, 2015, from http://www.jstore.org/stable/432098

Kadar, E. E., \& Effken, J. A. (2008). Paintings as Architectural Space: "Guided Tours" by Cézanne and Hokusai. Ecological Psychology, 20(4), 299-327. doi:10.1080/10407410802421874

L Rosin, P. (2001). On Serlio's Construction of Ovals. The Mathematical Intelligencer, Springer-Verlag, 23(1), 58-68.

Loran, E. (1950). Cézanne's Composition: Analysis of his Form, with Diagrams and Photographs of his Motifs. Berkeley: University of California Press.

Reff, T. (1977). Cézanne: The Late Work: Essays, (W. Rubin, Ed.). New York: Museum of Modern Art..

Rewald, J., \& Weitzenhoffer, F. (1989). Cézanne and America. London: Thames and Hudson.

Roger, F. (1971). Paul Cezanne, Ambroise Vollard, Paris 1915. The Burlington Magazine for Connoisseurs, 31(173), 52-55+57+6o.

Schapiro M. (1952) Paul Cezanne, USA: Harry N Abrams.

Smith P. (2013) Cezanne's "Primitive" Perspective, or the "View from Everywhere", The Art Bulletin, 95(1), 102- 119, Retrieved 15 December 2014 , from DOI: 10.1080/00043079.2013.10786108

Stalnaker, N. (1996). Another Look at the "Multiple Viewpoint" Theory: A Reply to Richardson. The Journal of Art Criticism, 54(3), 287- 290.Retrieved 17 Nov 2015, from http://www.jstor.org/stable/431632

Taylor, B. (1961). Cézanne. Italy: Hamlyn.

Yve-alain, B \& Krauss, R. (1998). Words and Deeds. October, 84 (spring), 31-43. Retrieved 16 Nov. 2015, from http://www.jstor.org/stable/779207

Mani Nandini Sharma is a research scholar in Department of Humanities and Social Sciences, Indian Institute of Technology Roorkee, Roorkee, Uttarakhand, India. Other than academics, she is a profesional artist, and genere is in semi abstract expression. She has put many art exhibitions in NCR and North India.

Prof. E Head. Ila Gupta, Arhitecture and Planning Department, (Joint Faculty- Department of Humanities and Social Sciences) IITR, Roorkee, India, is honored with Chancellor's Medal (1976), Merut University, India. She has designed logo, tie, flag, commemorative stamp of IIT Roorkee, India and also, logo of IIT Mandi, India. 